\title{
MATOS, Eusébio de. A paixão de Cristo senhor nosso: desde a instituição do Sacramento na ceia até a lastimosa soledade de Maria Santíssima. Apuração do texto José Américo Miranda e Nilton de Paiva Pinto; apresentação e notas José Américo Miranda. Belo Horizonte: Editora UFMG, 2007.
}

Sérgio Alves Peixoto Universidade Federal de Minas Gerais

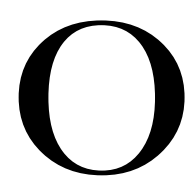

título que o professor José Américo Miranda escolheu para sua apresentação a esta paixão de Cristo, de Eusébio de Matos, mostra uma das grandes dificuldades da historiografia literária no Brasil, principalmente se ela se debruça sobre o período colonial: "Eusébio de Matos, um poeta possível".

Pouco se sabe da literatura que se produziu no Brasil quando colônia de Portugal, e recuperar esses textos é uma permanente conquista para quem se atribuiu a tarefa de resgatar nossa memória cultural-literária da época. Essa mesma dificuldade se dá, também, com nosso século XIX, repleto de autores ainda por serem estudados ou mesmo revistos com mais acuidade crítica, como nos diz o professor José Américo:

Transcorridos os séculos XIX e $\mathrm{XX}$, apesar dos esforços da inteligência brasileira para continuar revelando o Brasil ao Brasil e ao mundo, muito de nossa produção literária (e não somente do período colonial) permanece 
ignorada. Dito de outro modo: o próprio Brasil ainda tem muito que se conhecer. E no tocante aos estudos literários, o período colonial tem sido um permanente desafio, uma fonte de onde todo o dia surge um novo aspecto do Brasil desconhecido. Nos dias atuais, início do século XXI, o próprio século XIX já representa desafio idêntico.

Por isso, o livro de Eusébio de Matos que ora se edita é bem-vindo. Mesmo que o Eusébio-poeta não passe de um poeta possível. Se, além de possível, for ele também importante, melhor ainda.

Esse é o caso de Eusébio de Matos, renomado sermonista baiano, embora praticamente desconhecido no que diz respeito à poesia. Desconhecido, não só por normalmente nos lembrarmos dele somente por ter escrito sermões, mas também por, como seu irmão, Gregório, não ter assinado texto algum. O próprio professor José Américo informa, na sua nada barroca apresentação, que há indícios de que certos poemas pertenceriam a Eusébio porque, segundo Varnhagen, primeiro a publicar um texto atribuído a ele, o estilo em que foram escritos lembra o do autor do Ecce Homo, conjunto de práticas pregadas por Eusébio no Colégio da Bahia, e publicados em Lisboa, em 1667.

O que perguntaríamos é por que os sermões tiveram edições próprias e os poemas não? Uma possível resposta seria por ter sido Gregório mais atuante na poesia, eclipsando os versos do irmão. Aí entramos, mais uma vez, no campo das probabilidades.

Se, infelizmente, não podemos chegar a conclusões definitivas sobre a autoria dos poemas, diznos o apresentador, temos que nos pautar pelo que a tradição tem dito durante todo esse tempo. Aceitamos Eusébio, como ele aceitou a fé católica, sem precisar da certeza que estigmatizou, de certa forma, o apóstolo Tomé.

Um outro problema colocado no livro do professor José Américo foi o estabelecimento do texto que deveria ser tomado como base para a edição, isto é, dentre as variantes - e elas são muitas - quais as que deveriam ser escolhidas para se conseguir o tão almejado texto "definitivo".

Diferentemente de James Amado, que preferiu, no caso de Gregório de Matos, o texto mais palatável aos olhos e aos ouvidos do leitor moderno, José Américo, juntamente com Nilton de Paiva Pinto, optaram pelo princípio da lectio difficilior, isto é, o texto de leitura mais intrincada, o de mais difícil compreensão, guiando-se, ambos, pelas idéias de Segismundo Spina, para quem o texto mais fácil indicaria que alguém, durante o transcorrer dos anos, ali 
tocara, colocando "em linguagem inteligível aquilo que não entenderam no manuscrito copiado". Assim sendo, coube aos apuradores do texto de Eusébio de Matos a tarefa de comentar as dificuldades encontradas, interpretando passagens difíceis e mesmo sugerindo leituras possíveis para determinados momentos em que não havia a menor possibilidade de compreensão por parte do "pobre" leitor.
Ainda bem que a busca pelo mais difícil se restringiu somente ao que diz respeito ao estabelecimento do texto, e não à linguagem usada pelo apresentador. Esperamos que ele continue a fazer das impossibilidades estratificadas um desafio, e nos traga outros escritores esquecidos nas estantes de nossas bibliotecas. São eles que fazem nossa imagem; são eles que a projetam para o mundo. 